\title{
The Preoccupation of the United Nations with Israel: Evidence and Theory
}

\author{
Raphael N. Becker \\ Arye L. Hillman \\ Niklas Potrafke \\ Alexander H. Schwemmer
}

CESIFO WORKING PAPER NO. 5034

CATEgory 2: Public ChOICE

OCTOBER 2014
An electronic version of the paper may be downloaded
- from the SSRN website: Www.SSRN.com
- from the RePEc website: $\quad$ www.RePEc.org
- from the CESifo website: www.CESifo-group.org/wp




\title{
The Preoccupation of the United Nations with Israel: Evidence and Theory
}

\begin{abstract}
We compiled data on all United Nations General Assembly resolutions on which voting took place between January 1990 and June 2013 and find a preoccupation with one country: in 65 percent of instances in which a country is criticized in a resolution, the country is Israel, with no other country criticized in more than 10 percent of resolutions. We use comparative quantitative criteria to confirm that Israel is subject to discrimination. To explain the motives for discrimination, we present a model of behavioral political economy that includes decoy voting, vanity of autocrats, and a Schelling focal point for deflection of criticism. The model includes a role for traditional prejudice. Our conclusions more generally concern political culture in the United Nations.
\end{abstract}

JEL-Code: Z120.

Keywords: United Nations General Assembly voting, expressive voting, decoy voting, focal point, logrolling, discrimination, prejudice, political culture.

Raphael N. Becker

Department of Economics

University of Bonn

Germany - 53113 Bonn

s6rabeck@uni-bonn.de

Niklas Potrafke*

Ifo Institute - Leibniz Institute for

Economic Research

at the University of Munich

Poschingerstrasse 5

Germany - 81679 Munich

potrafke@ifo.de
Arye L. Hillman

Department of Economics

Bar-Ilan University

Israel - Ramat Gan 5290002

arye.hillman@biu.ac.il

Alexander H. Schwemmer

Department of Law and Economics

University of Bayreuth

Germany

alexander.schwemmer@gmail.com

${ }^{*}$ corresponding author

This paper has been accepted for publication in the Review of International Organizations. 


\section{Introduction}

Between January 1990 and June 2013, there were 1676 resolutions of the United Nations General Assembly on which votes were taken. ${ }^{1}$ Of these resolutions, 744 did not relate to a particular country, 932 mentioned a country, 646 criticized a country, and 272 praised a country. Table 1 shows the distribution of the resolutions by country (the most prominently appearing 26 countries). ${ }^{2}$

There are 480 resolutions in table 1 involving Israel, either directly or in relation to neighboring countries and populations. Of the resolutions in which Israel is involved, 422 or 88 percent criticize Israel, either explicitly or implicitly. Criticisms are varied and include accusations of human rights violations, although Israel is also included in criticism more generally applied to a number of countries for refusal to participate in anti-nuclear proliferation. ${ }^{3}$

\footnotetext{
${ }^{1}$ The sessions of the United Nations General Assembly begin annually in September. Votes up to June 2013 were thus during the 67th session that began in September 2012. Many resolutions pass by acclamation (Hug 2012). Such resolutions often set out visions for a better future, as for example described in "We the Peoples: The Role of the United Nations in the 21st Century" (Kofi Annan 2000) and "Building a Better Future for All" (Ban Ki-moon 2013). Included in this category are resolutions such as those setting out the Millennium Development Goals, which announced targets for improvements in development indicators in low-income countries (United Nations General Assembly 2000; United Nations Millennium Project 2005). Resolutions on which no vote was taken also relate to procedural matters such as financial and budgetary aspects of the United Nations, rules of procedure concerning languages, and appointment of temporary staff.

2 The numbers in table 1 add to more than the total number of resolutions because some resolutions relate to more than one country.

${ }^{3}$ The number of 422 resolutions in table 1 in which Israel is criticized is based on a narrow criterion of criticism. The number of resolutions that can be counted as criticizing Israel increases substantially when broader criteria of criticism are applied. The following is a list of 10 categories of resolutions that do not explicitly name but implicitly criticize Israel: Financing for the United Nations Relief and
} 
Following Israel (422) in table 1 in being criticized are South Africa (59), the United States of America (39), North Korea (38), Palestine (29), Iraq (22) and Iran (22). South Africa appears because of Apartheid policies at the beginning of the data period.

The feature of table 1 is the asymmetry whereby Israel is involved in 65 percent of all resolutions criticizing a country whereas no other country appears in more than 10 percent of resolutions. Our objective is to explain the focus of attention - and the focus of criticism on Israel in table 1.

An explanation that might be proposed is bias in a context of historical discrimination: just as Jews over the centuries have been subjected to adverse discrimination through antisemitism, so the recreated Jewish state might be subject to adverse discrimination through the "new antisemitism." Yet, as we shall note, given the identity of the countries voting to criticize Israel, the criticism cannot be explained as a continuation of a tradition of antisemitism. 4

Works Agency for Palestinian Refugees in the Near East (6 resolutions); Rights of the Palestinian people to self-determination (10 resolutions); Inalienable rights of the Palestinian people (43 resolutions); Support for peace process (4 resolutions); Palestinian refugees (13 resolutions); Dissemination of information about Palestine (1 resolution); Day of Solidarity with the Palestinian people (20 resolutions); Recognition of Palestine (1 resolution). Adding these ten categories increases the number of resolutions criticizing Israel by 98 . If mentioning of "Palestine" is regarded as criticizing Israel, the number of resolutions criticizing Israel increases by 115 . The number of resolutions involving criticism of Israel increases by 13 when we consider as criticism being a non-ratifying state in Annex 2 of the Comprehensive Nuclear-Test-Ban Treaty (see http://www.ctbto.org/the-treaty/status-ofsignature-and-ratification/?states $=4 \& c H a s h=a 4723384083 \mathrm{f} 2 \mathrm{~d} 3751391011 \mathrm{cdcbdee} 0$, accessed $17 \mathrm{Sep}-$ tember 2014). Inclusion as a non-ratifying Annex 2 country together with mentioning of Palestine results in an addition of 128 resolutions in which Israel is criticized. We include in our categorization "Nuclear Weapon States," which is a source of criticism for China, France, Great Britain, the Russian Federation and the United States.

${ }^{4}$ Discrimination against the state of Israel has been described as the "new antisemitism." See, for example, Forster and Epstein (1974) and Judaken (2008). 
A suggested explanation for table 1 could be that there is no bias and that Israel should deservedly be criticized in 65 percent of the resolutions over the data period. We show, however, using comparative data sources, that the focus of criticism on Israel is inconsistent with events during the data period.

With neither traditional antisemitism nor comparative data explaining the focus of attention on Israel in table 1, there is a puzzle to be resolved. We propose an explanation for the voting record in table 1 based on the theory of identity-based expressive behavior (Hillman 2010). The theory describes behavior that provides utility through expression of identity. ${ }^{5}$ The identity expressed need not be true identity. ${ }^{6}$

Voting in the United Nations General Assembly is expressive because resolutions are non-binding and thus do not oblige actions. Voting is usually in blocs. A bloc composed of autocracies and "weak democracies" (meaning that elections take place but the rule of law is not assured, allowing a ruler, as in autocracies, to persist in office over time) has an automatic majority and is therefore decisive in determining majority-voting outcomes. ${ }^{7}$

\footnotetext{
${ }^{5}$ Expressive utility resolves the "paradox of voting" that, for non-decisive voters, the time and other costs of voting exceed the material benefits (see Brennan and Hamlin 2000, Engelen 2006, Hillman 2010, Hamlin and Jennings 2011, and Brennan and Brooks 2013). The identity-based theory of expressive behavior (Hillman 2010) proposes that, through the low-cost activities of voting and rhetoric, individuals express an identity to themselves or to others. See also Glazer (2008) on "voting to anger and to please others." For other perspectives on identity, see Akerlof and Kranton (2010).

${ }^{6}$ Tullock (1971), for example, described individuals who vote contrary to their true identity of being uncharitable in expressively supporting income redistribution with the knowledge that their single vote will not be decisive.

${ }^{7}$ Voting blocs in the United Nations are long-established. See Hovet (1960), Iida (1988), and Kim and Russett (1996). On bloc-voting in the United Nations Human Rights Council, see Hug and Lukács (2014).
} 
Against this background, we propose that the focus on Israel in table 1 is explained by decoy voting. Our model describes Israel as a decoy or Schelling focal point (Schelling 1978) for criticism. Autocratic rulers and governments require repression for regime security but benefit expressively by portraying themselves as benevolent and not as imposing themselves on their people. The autocratic rulers and governments would lose esteem if criticized in United Nations resolutions. Decoy voting distracts attention from the acts of repression required by autocratic rulers and governments for regime security. ${ }^{8}$

We set out the model of decoy voting in section 2. In section 3 we use comparative quantitative criteria to confirm that Israel is subject to discrimination in United Nations voting. We also compare discrimination through decoy voting with discrimination based on traditional prejudice. Section 4 provides concluding remarks.

\section{A theory of decoy voting}

\subsection{Background to the theory: patters of UN voting}

The voting in blocs in the United Nations is akin to voting by political parties. The voting blocs are present in the resolutions in which the state of Israel is criticized. Table 1 shows that the average majority in a vote involving Israel is 87.4 percent. A review of the data on voting on the resolutions reveals that this majority is an average of dichotomous voting outcomes. In some 20 percent of resolutions, at least 40 governments support Israel or abstain. In the other 80 percent of resolutions, there are large supermajorities in votes against Israel, with support for Israel confined to a small number of governments (a voting bloc usually composed of Australia, Canada, the United States, Israel itself, and Pacific island states - the Marshall Islands, the Federated States of Micronesia, Nauru, and Palau). A majority in reso-

\footnotetext{
${ }^{8}$ See also Herne (1997) for another perspective on decoy voting.
} 
lutions criticizing Israel is a foregone conclusion. The only question is which of the dichotomous outcomes arises, which depends on voting by the European bloc. ${ }^{9}$

A bloc that has been known as the "Third World" consistently votes against Israel, as does an Arab or Muslim bloc that has in general been part of the "Third World" coalition. "Third World" countries are autocracies, or are "weak democracies". Our decoy-voting theory does not distinguish between autocracies and "weak democracies": both consistently vote against Israel in the United Nations and in both cases rulers have an interest in justifying persistence in office. ${ }^{10}$

The Arab or Muslim bloc consists of autocracies. ${ }^{11}$ The bloc regards Israel as an illegitimate state and consistently votes to criticize Israel. ${ }^{12}$

\footnotetext{
${ }^{9}$ Appendix 1 shows voting by countries on representative resolutions of the category of resolutions in which there are large supermajorities in votes against Israel.

${ }^{10}$ On "weak democracies", see Carothers (2002), who refers to a "Gray Zone" from which few true functioning democracies emerged.

${ }^{11}$ On democracy and Arab or Muslim countries, see for example Fish (2002), Borooah and Paldam (2007), and Potrafke $(2012,2013)$.

${ }^{12}$ All Arab and Muslim member countries opposed the UN General Assembly resolution of November 291947 that gave formal recognition to a recreated state of Israel (13 governments voted against: Afghanistan, Cuba, Egypt, Greece, India, Iran, Iraq, Lebanon, Pakistan, Saudi Arabia, Syria, Turkey, and Yemen; there were 10 abstentions: Argentina, Chile, China (Taiwan), Colombia, El Salvador, Ethiopia, Honduras, Mexico, United Kingdom, and Yugoslavia; all other UN member states of the time voted in favor: Australia, Belgium, Bolivia, Brazil, Byelorussian S.S.R., Canada, Costa Rica, Czechoslovakia, Denmark, Dominican Republic, Ecuador, France, Guatemala, Haiti, Iceland, Liberia, Luxemburg, Netherlands, New Zealand, Nicaragua, Norway, Panama, Paraguay, Peru, Philippines, Poland, Sweden, Ukrainian S.S.R., Union of South Africa, U.S.A., U.S.S.R., Uruguay, Venezuela). The UN plan called for partition between a Jewish and Arab state. The government of Israel accepted the UN partition plan, Palestinians and surrounding Arab states did not. Arab forces invaded and lost an ensuing war (with the exception of Transjordan, the army of which had British officers). Until the
} 
Rulers and populations in "Third World" (excluding Muslim) countries in general do not have a history or tradition of prejudice against the Jewish people that would underlie prejudice against Israel as a Jewish state. Members of the "Third World" bloc in the United Nations have diplomatic relations with Israel and have received technical development aid from Israel. ${ }^{13}$ An explanation other than a tradition of prejudice is therefore required to explain the persistent "Third World" voting against Israel.

\subsection{Expressive behavior as decoy voting}

With resolutions of the United Nations General Assembly non-binding, and with voting also visible rather than anonymous, voting on the resolutions can be regarded as expressive. Through expressive voting, countries signal identity, or display sought attributes. Signalling also takes place and identity is displayed in debate and rhetoric.

For autocratic rulers (or rulers of "weak democracies"), the display of identity through voting and rhetoric in the United Nations is personal. The rulers may view themselves as personifying their country. Autocratic rulers who arrive for the General Assembly meetings, or who send their representatives, do not wish their countries and governments, or themselves, to be criticized among peers. Out of vanity, the rulers and governments wish to portray themselves as benevolent and "loved by the people." After mass killing of people subject to his rule had begun, Bashar Al-Assad, as ruler of Syria, for example declared:

\footnotetext{
"six-day-war" of 1967, Jordan (renamed from Transjordan) occupied the "west bank" (of the Jordan River). Before and after 1967, Arab and Muslim states have voted in the United Nations against Israel. ${ }^{13}$ At the end of our data period, there were 193 member countries of the United Nations besides Israel, of which 160 (83 percent) had diplomatic relations with Israel. Development assistance by Israel to low-income countries is provided through MASHAV, the aid agency of the government of Israel. See http://mfa.gov.il/MFA/mashav/AboutMASHAV/Pages/default.aspx (accessed 26 June 2014).
} 
"The state is like a mother or father who embraces everyone and accommodates all her children."14

Muammar Gaddafi, as dictatorial ruler of Libya confronting rebellion, declared:

"They love me. All my people are with me."15

More generally, Rowley (2000) described the self-attributed paternalistic identity of the "strong men" of countries of sub-Saharan Africa. Martin (2006) described the selfproclaimed "loving care of the fatherly leader" of North Korea.

Criticism in United Nations resolutions of autocratic rulers and governments would result in loss of esteem (Brennan and Pettit 2004). At home, the autocratic governments can suppress criticism. Suppression of criticism is likewise an objective in the United Nations, where portrayal of a benevolent identity is therefore sought. Benevolent identity is counter to the necessities of regime security, which require autocratic rulers and government to be non-compromising and non-benevolent. ${ }^{16}$

Display of benevolent identity is facilitated by choosing a decoy as a Schelling focal point for criticism. The purpose of debate and voting regarding the decoy is therefore not reaching understanding or conciliation but to direct criticism and blame at the decoy. Be-

14 https://arabrevolt.wordpress.com/2011/06/20/speech-bashar-al-assad-june-20-2011/ (accessed 25 April 2014).

15 http://www.euronews.net/2011/03/01/my-people-love-me-libya-s-gaddafi/ (accessed 25 April 2014).

${ }^{16}$ Autocracy is in general inconsistent with benevolent government (Easterly 2011) and with political compromise (Dixit, Grossman and Gul 2000). Threats to security of autocratic rulers and governments arise when the ruling elites - often clan or tribe-based - face internal opposition. See Alesina et al. (2003) on domestic divisions or "fractionalization." Horowitz (1985) describes the impediments to democracy in clan or tribal-based societies. In describing procurement bribery and rent extraction, Gupta et al. (2001) provide evidence on military spending by autocratic governments that confront no external threat. 
cause of these circumstances, behavior toward the decoy in the United Nations has been described as theatrical:

"What takes place [is not] a political debate or an attempt at problem-solving. Israel is cast as the villain in [a] melodrama."17

\subsection{The model of UN voting by autocracies}

\subsubsection{Summary of the model}

The model describes autocratic rulers as incurring expressive disutility through loss of esteem if criticized in a UN resolution and as benefitting expressively from the opportunity in the United Nations to criticize and distract attention to someone else. Autocratic rulers also benefit non-expressively or materially from regime security through repression of opposition in their home countries. ${ }^{18}$ Repression is costly in expressive terms if there is criticism in a UN resolution and is also costly in material terms. ${ }^{19}$ In the absence of the possibility of UN resolutions, rulers choose repression to maximize utility through regime security with no constraint of expressive disutility from criticism. UN censure resolutions introduce the possibility of criticism. The Nash equilibrium with censure resolutions is a case of the tragedy of the commons: each autocratic ruler benefits from display of benevolent identity by criticizing other autocratic rulers for the repression that each autocratic government requires for regime security. The disutility of mutual criticism is avoided by a logrolling agreement

\footnotetext{
${ }^{17}$ Jean Kirkpatrick (1983), U.S. representative to the United Nations, quoted by Rosen (2010).

${ }^{18}$ In exposition, we do not now distinguish between autocracy and "weak democracy". The objectives with regard to regime security and criticism are the same whether or not institutions are formally democratic.

${ }^{19}$ Gupta et al. (2004) provide evidence on the economic costs of internal conflict through the government budget and economic growth.
} 
whereby autocratic governments agree not to criticize one another and choose a decoy as the unique Schelling point for criticism. The effectiveness of the decoy increases with the magnitude of the majority in decoy resolutions. The decoy is therefore chosen as the country against which the greatest majority will be obtained in decoy voting, which entails maximizing supportive decoy votes from governments outside the autocratic logrolling coalition. The model predicts the focus of criticism on one country in table 1.

\subsubsection{Repression without the discipline of UN criticism}

We describe $n$ autocrats as each choosing a level of repression $R_{i}$ to maximize utility consisting of respective expressive and material components $V_{i}$ and $M_{i}{ }^{20}$

$$
U_{i}=V_{i}+M_{i} \quad i=1, \ldots n \text {. }
$$

where

$$
M_{i}=B_{i}\left(R_{i}, \theta_{i}\right)-C_{i}\left(R_{i}, \theta_{i}\right) .
$$

In (2), $B_{i}$ is material benefit from regime security. $C_{i}$ is the material or resource cost of repression. $B_{i}$ and $C_{i}$ depend on political institutions $\theta_{i}$. Larger $\theta_{i}$ indicates more autocratic government. Accounting for a corner solution at zero, $R_{i}$ is determined from:

$$
R_{i} \cdot\left[\frac{\partial B_{i}\left(R_{i}, \theta_{i}\right)}{\partial R_{i}}-\frac{\partial C_{i}\left(R_{i}, \theta_{i}\right)}{\partial R_{i}}\right]=0, \quad i=1, . ., n
$$

In an interior solution, repression chosen from (3) increases with $\theta_{i}$ (when the country's institutions are more autocratic).

\footnotetext{
${ }^{20}$ See Hillman (2010) for the utility function. Additivity is assumed in (1). We do not state evident concavity and convexity assumptions.
} 


\subsubsection{The discipline of UN censure resolutions}

UN censure resolutions introduce the prospect of loss of esteem from being criticized and also the opportunity for expressive benefit from deflecting attention from own actions by criticizing others. An autocratic ruler $i$ has expressive utility $\bar{V}_{i j} \geq 0$ from voting in favor of a resolution that censures another government $j$ and incurs expressive disutility $\tilde{V}_{j i} \leq 0$ if criticized in a censure resolution by government $j$. Greater majorities in censure resolutions increase expressive benefit $\bar{V}_{i j}$ of government $i$ from voting in support of a resolution that censures government $j$. The disutility $\tilde{V}_{j i}$ of government $i$ from being censured by government $j$ likewise increases with the size of the majority in the censure resolution. ${ }^{21}$

The probability $P_{i}$ that a censure resolution against government $i$ comes to the vote increases with government $i$ 's repression and declines with repression by other governments:

$$
P_{i}=P_{i}\left(R_{1}, R_{2,} \ldots, R_{n}\right), \frac{\partial P_{i}}{\partial R_{i}}>0, \frac{\partial P_{i}}{\partial R_{j}}<0 j \neq i
$$

In independent voting, after the country that is the subject of a resolution has been determined by (4), utility is maximized by no government voting to criticize itself and each government voting to censure any other government.

We denote by $\bar{V}_{i, n-1}$ the utility of government $i$ from being one of the (n-1) governments that votes to censure government $j$ and by $\tilde{V}_{i, n-1}$ the disutility of being censured in a resolution supported by all other (n-1) governments. In the utility function (1), the expressive component of utility is:

\footnotetext{
${ }^{21}$ The identity of a government that votes to censure - or not - also usually matters. A generalization assigns weights to utility or disutility according to the country voting for or against.
} 


$$
V_{i}=P_{i}\left(R_{1}, R_{2}, \ldots, R_{n}\right) \tilde{V}_{i, n-1}+\left[1-P_{i}\left(R_{1}, R_{2}, \ldots, R_{n}\right)\right] \bar{V}_{i, n-1} \quad i=1, . ., n
$$

with

$$
\frac{\partial V_{i}}{\partial R_{i}}=\frac{\partial P_{i}}{\partial R_{i}}\left[\tilde{V}_{i, n-1}-\bar{V}_{i, n-1}\right]<0 \quad i=1, . ., n
$$

In (6), increased repression, by making a censure resolution more likely, increases the likelihood of disutility from censure and also increases the likelihood of forgoing utility by not having the opportunity to vote to censure someone else. Repression subject to the discipline of UN censure resolutions is determined by:

$$
\frac{\partial B_{i}}{\partial R_{i}}=\left[\frac{\partial C_{i}}{\partial R_{i}}-\frac{\partial V_{i}}{\partial R_{i}}\right]>\frac{\partial C_{i}}{\partial R_{i}} \quad i=1, . ., n .
$$

and thus is larger than without discipline of UN censure.

\subsubsection{Logrolling and a tragedy of the commons}

A logrolling agreement ends disutility from the prospect of being censured. The logrolling agreement is enforceable because voting is visible. Also, there is no incentive to defect from the majority coalition. With logrolling:

$$
P_{i}=0, \quad i=1, . ., n
$$

and thus

$$
\frac{\partial V_{i}}{\partial R_{i}}=0, \quad i=1, . ., n
$$

whereupon it follows that:

$$
\frac{\partial B_{i}}{\partial R_{i}}=\frac{\partial C_{i}}{\partial R_{i}} \quad i=1, . ., n .
$$


The condition (10) is equivalent to (3), which describes choice of repression in the absence of UN resolutions. Through logrolling, the discipline of censure resolutions is therefore avoided.

Rather than governments being subject to a censure resolution based on the probability (4), simultaneous votes can take place on $n$ censure resolutions - one for each autocracy. In the Nash equilibrium, each of the $n$ governments votes to censure the other $(n-1)$ governments. The mutual censure is a case of the tragedy of the commons. The Nash equilibrium is avoided by cooperation through logrolling. ${ }^{22}$

\subsubsection{The decoy}

In the logrolling equilibrium, the $n$ autocratic governments have no one to criticize. A decoy chosen as a Schelling focal point restores utility from criticizing someone else. Greater majorities in decoy voting validate criticism of the decoy. The optimal decoy is the country that attracts the greatest support from outside the autocratic coalition in decoy resolutions.

\subsection{The voting incentives of democracies}

The above model of decoy voting refers to autocracies or governments that require repression for internal regime security. We do not present a parallel formal model of voting by democracies. We note the benefits and costs associated with participation in decoy voting by governments of democracies.

\subsubsection{Within-UN benefits}

\footnotetext{
${ }^{22}$ Participation in logrolling requires that the expressive disutility when criticized by the other $(n-1)$ governments be greater than the expressive utility from voting to criticize the $(n-1)$ governments.
} 
Governments of democracies benefit from within-UN logrolling agreements with autocratic governments. Membership of the Security Council is determined by General Assembly voting. The prestige from Security Council membership can be accompanied by financial benefit (see Kuziemko and Werker 2006; Dreher, Sturm and Vreeland 2009). UN voting determines membership of various other UN committees and subcommittees (Fasulo 2004).

\subsubsection{Personal benefits}

There are personal career benefits for a country's diplomats from expanded representation and activity within international organizations (Vaubel and Willett 1991).23 National politicians who can give directives for voting to UN delegations also benefit personally from congeniality in relations with autocratic regimes. ${ }^{24}$ The personal benefits can influence decisions whether to join in decoy voting.

\subsubsection{Ethics}

The decision of a government of a democracy regarding participation in decoy voting can be influenced by ethics. A judgment can be made whether participation in decoy voting is ethical.

\footnotetext{
${ }^{23}$ The personal benefits include invitations to social events such as countries' independence-day and national-day celebrations.

${ }^{24}$ For example, in February 2011, the French foreign minister resigned from office amid revelations that she had offered French anti-riot police to the autocratic ruler of Tunisia to repress demonstrators seeking democracy. She had spent her year-end vacation in Tunisia, traveling in a private plane belonging to a businessman with links to the Tunisian ruler. Some short time before demonstrations ended the rule of Hosni Mubarak of Egypt, the French Prime Minister had flown to Egypt in a private plane together with his family as a guest of the ruler of Egypt for an end-of-year vacation. http://www.theguardian.com/world/2011/feb/27/french-foreign-minister-resigns (accessed 2 May 2014).
} 


\subsubsection{Intimidation}

Intimidation has been observed in the United Nations:

"Other nations become progressively more reluctant to associate themselves with the accused (the decoy in our model), out of fear that they themselves will become the target of bloc hostility."25

\subsection{Uniqueness of the decoy}

A Schelling focal point is unique. The evidence from the voting record in table 1 shows a unique decoy.

\section{Is there discrimination?}

Decoy voting entails discrimination - against the decoy. In the absence of discrimination, there is no phenomenon or puzzle to be explained in the voting record in table 1 . Discrimination is suggested impressionistically from an overview of world events over the data period. We turn to quantifiable comparative evidence and data on the issue of discrimination.

\subsection{Deaths and human rights}

As a comparative indicator, we use the number of battle-related fatalities as prepared by the International Peace Research Institute (PRIO). ${ }^{26}$ We also use the Cingranelli-Richards Human Rights data (CIRI). ${ }^{27}$ The Physical Integrity Rights Index "is an additive index constructed from the Torture, Extrajudicial Killing, Political Imprisonment, and Disappearance

\footnotetext{
${ }^{25}$ Jean Kirkpatrick, U.S. representative to the United Nations, as quoted by Rosen (2010).

${ }^{26}$ We use the number of all deaths caused by hostilities in which an individual government is involved as a primary warring party.

${ }^{27}$ See Cingranelli and Richards (2010). We accessed the data online on 15 January 2014.
} 
indicators. The Index ranges from 0 (no government respect for these four rights) to 8 (full government respect for these four rights)" and the new Empowerment Rights Index, which is "an additive index constructed from the Freedom of Movement, Freedom of Speech, Workers' Rights, Political Participation, and Freedom of Religion indicators. This Index ranges from 0 (no government respect for these five rights) to 14 (full government respect for these five rights)." We relate the number of deaths and human rights violations to the number of UNGA resolutions criticizing individual countries. We focus on the six countries that have been criticized most often (see Table 1): Israel, South Africa, the United States of America, North Korea, Iraq, and Iran. We show results averaged over the period 1990-2012 and for individual years. Building averages over time neglects that in some countries violations and resolutions refer to a short period of time, while in others conflict is ongoing over years.

Table 2 shows the results for Israel. Column (2) shows the number of resolutions criticizing Israel in an individual year. Column (3) shows the number of resolutions criticizing Israel as a share of all resolutions criticizing a country in an individual year. Column (4) shows the number of battle-related fatalities and column (5) the number of battle-related fatalities per resolution criticizing Israel. Columns (6) and (7) show the Physical Integrity Rights Index and the new Empowerment Rights Index. Over the period 1990-2012, there were 5400 battle-related fatalities relating to Israel, meaning 13 battle-related fatalities per resolution criticizing Israel. The averaged Physical Integrity Rights Index assumed the value 3 (on a scale from 0 to 8); the New Empowerment Rights Index assumed the value 7 (on a scale from 0 to 14$)$.

We account for the time dimension. Deaths that occurred in one year could not result in the same number of resolutions as deaths that occurred over the course of years. The resolutions involving Israel tend to have constant periodicity over time. In section 3.2 we 
show how the resolutions involving Israel are for the most part repeated every year without regard for events that occurred.

Tables 3 and 4 show the results for South Africa and North Korea. The PRIO dataset does not include data on battle-related fatalities for South Africa and North Korea. The averaged Physical Integrity Rights Index took the values 3 and 0; the new Empowerment Rights Index took the values 11 and 0 . In particular, the CIRI data predict severe human rights violations by North Korea that did not give rise to a plethora of UNGA resolutions criticizing North Korea. ${ }^{28}$

Table 5 shows 4312 battle-related fatalities relating to the United States over the period 2001-2012. There were 17 UNGA resolutions criticizing the United States over the period 2001-2012.

Tables 6 and 7 show the results for Iran and Iraq. The CIRI data predict severe human rights violations by Iran and Iraq. However, there were only a few resolutions criticizing Iran and Iraq. Deaths were mostly ongoing over the course of years, giving scope for UN resolutions that were not tabled and therefore on which no voting took place.

\subsubsection{Human rights violations by regimes under threat}

Neumayer (2013) presents evidence that autocracies significantly increase human-rights violations when states of emergency are declared, as do, but less so, countries in which control of government is contested (anocracy), while human-rights violations do not occur in democracies. The routine repression by autocracies for regime security is not reflected in

\footnotetext{
${ }^{28}$ On famine in North Korea in which it is estimated that between 600,000 and 2.5 million people starved to death, see Demick (2009). The ruler of North Korea decreed markets in food illegal. Resort to the market would show lack of faith in the ability of the ruler to fulfil the responsibility of feeding the people.
} 
resolutions in which countries are criticized in table 1, indicating - as predicted by our model - success of autocracies at avoiding UN censure resolutions.

\subsection{Discrimination through automatic repetitions of resolutions}

Discrimination against Israel is suggested by the repetition of UN resolutions verbatim every year independently of actions taken by the government of Israel. An administrative mechanism for the uniquely repeated resolutions is a special permanent $\mathrm{UN}$ committee with a mandate to focus exclusively on Israel. ${ }^{29}$ Tables $8-10$ show examples of repeated resolutions. A vote in favor of the resolution is a vote against Israel. The repeated resolutions are in the category of the 80 percent of resolutions in which fewer than 40 countries support Israel or abstain. We note the large supermajorities in favor of criticizing Israel. The supermajorities are consistent with - or are as predicted by - our decoy-voting model..$^{30}$

\subsection{Occupation of territory}

Table 10 shows voting on an accusation of "occupying territories." Discrimination is suggested in table 1 by the absence of resolutions relating to various countries that "occupy territories" and by the definition of "occupied territory" applied in the case of Israel. ${ }^{31}$

\footnotetext{
29 "The Special Committee to Investigate Israeli Practices Affecting the Human Rights of the Palestinian People and Other Arabs of the Occupied Territories."

${ }^{30}$ The Appendix to this paper, available online, shows how individual countries voted on the resolutions in tables 8-10 in a representative year 2009. There is little variation in how countries voted on the resolutions over time.
}

31 A comparison can be made with Morocco and Mauritania, which occupy without international recognition the territory previously known as the Western Sahara and have been in conflict during our data period with the Polisario Front composed of indigenous inhabitants of the region. Neither Morocco nor Mauritania appears in table 1. In various other regions in the world, territory is contested without criticism in UN resolutions of countries involved. In the case of Israel, the issue of "occu- 


\subsection{Definition of refugees}

Discrimination is also indicated by the definition of refugees uniquely applied with reference to Israel. UN resolutions criticizing Israel relate to Arab (not Jewish) refugees associated with the Israel-Arab conflict. Refugees were created in various locations around the time of the Arab-Israeli war of 1947-1948.32 The United Nations applies a unique definition of refugees in the context of the Israel-Arab conflict, whereby every descendant of a refugee and that person's subsequent descendants are also refugees. With refugee status uniquely intergenerationally conferrable, Palestinian refugee issues are assured as permanent issues for debate and voting in the United Nations.

\subsection{Human-rights accusations}

The resolutions in table 9 that accuse Israel of human-rights violations are repeated automatically over time without reference to particular acts. There are documented issues of bias in reports of human-rights NGOs regarding Israel. ${ }^{33} \mathrm{UN}$ resolutions, which are often based

pied territories" is controversial. Under international law, "occupied" territory is land taken from another country. The annexation of the "west bank" by Jordan in 1950 was recognized de jure only by Britain and Pakistan. In 1967 control of the "west bank" passed to Israel and in 1988 the Kingdom of Jordan renounced claim to the "west bank." UN resolutions nonetheless take the position that the "west bank" is occupied territory. Although Egypt, which controlled Gaza up until 1967, never annexed Gaza, the same claim is made in UN resolutions with respect to Gaza.

${ }^{32}$ For example, some 14 million refugees were created in the India-Pakistan partition of 1947. Large numbers of refugees were created in Europe in 1945 when Germans had to leave Sudetenland and former eastern territories. Jewish refugees were created when Jews had to leave Arab countries.

${ }^{33}$ Reports of NGO bias are compiled and available at http://www.ngo-monitor.org. For criticism of the principal human-rights NGO, Human Rights Watch, which is a major source of data for UN reports, by its founder for bias against Israel, see

http://www.nytimes.com/2009/10/20/opinion/20bernstein.html?_r=0(accessed 23 July 2014) 
on information from the NGOs, have quite usually defined self-defense by Israel as aggression. ${ }^{34}$ The human-rights record compiled by the U.S. State Department does not find that Israel engaged in the human-rights accusations over the data period of table $1 .{ }^{35}$

\subsection{Awareness of discrimination}

Bias in the United Nations has long been recognized (Donnelly, 1988). Discrimination against Israel has in particular been noted. Kofi Annan, secretary-general of the United Nations, declared that countries should not hold

After publicity and complaints, Human Rights Watch was obliged to dismiss a staff member involved in compiling data on Israel because the staff member had a Nazi fetish. See http://www.nytimes.com/2009/10/20/opinion/20bernstein.html (accessed 23 July 2014), http:/ / www.ngo-monitor.org/article.php?viewall=yes\&id=2456 (accessed 23 July 2014), and http://www.guardian.co.uk/world/2009/sep/15/human-rights-watch-nazi-israel (accessed 23 July 2014).

${ }^{34}$ See for example the Goldstone Report (United Nations Human Rights Council 2009), which accused the government of Israel of wantonly firing on civilians. The accusations were, in this case, retracted by the principal author of the Report, although not by the United Nations. See http://www.washingtonpost.com/opinions/reconsidering-the-goldstone-report-on-israel-and-warcrimes/2011/04/01/AFg111JC_story.html (accessed 23 July 2014). On the Goldstone resolutions and the Goldstone retraction, see Hillman and Potrafke (2014).

35 The U.S. State Department Human-Rights Report (2010) for 2009 is representative. Under Arbitrary or Unlawful Deprivation of Life, the report states: "The government (of Israel) or its agents did not commit politically motivated killings;" for Disappearance: "There were no reports of politically motivated disappearances during the year." Under Torture and Other Cruel, Inhuman, or Degrading Treatment or Punishment, the Report notes that: “A 1999 High Court of Justice ruling held that, although torture and the application of physical or psychological pain are illegal, ISA (Security Service) interrogators may be exempt from criminal prosecution if they use such methods in extraordinary "ticking bomb" cases." Under Denial of Fair Public Trial, the Report states that: "The law provides for an independent judiciary, and the government respected this provision in practice. The judiciary has ruled against the executive, including in security cases."

http://www.state.gov/j/drl/rls/hrrpt/2009/nea/136070.htm (accessed 23 July 2014). 
"Israel to a standard of behavior they are unwilling to apply to other States, to Israel's adversaries, or indeed to themselves." 36

Annan continued:

"Some may feel satisfaction at repeatedly passing General Assembly resolutions. There have been decades of resolutions. .. Has any of this had an effect on Israel's policies, other than to strengthen the belief in Israel, and among many of its supporters, that this great Organization is too one-sided?"37

The purpose of the resolutions is, in line with our model, not to change outcomes but to allow governments to "feel satisfaction" from having the decoy to criticize. Annan showed awareness of the decoy role in declaring that the United Nations should not use Israel to "monopolize attention." 38

\subsection{Antisemitism}

Given the evidence showing discrimination, does the decoy-voting model provide the appropriate or only explanation for the discrimination? An alternative explanation is the historical prejudice known as antisemitism. We have noted that "Third World" countries (Arab

\footnotetext{
${ }^{36}$ Speech to the UN Security Council, December 12 2006, selected phrases. See

http:// www.unwatch.org/site/apps/nl/content2.asp?c=bdKKISNqEmG\&b=1317481\&ct=3354413. (accessed July 23 2014).

${ }^{37}$ Ibid.

${ }^{38}$ It is noteworthy, given the suggestions of intimidation, that Kofi Annan made his remarks at the end of his term as secretary-general of the United Nations. The evidence that the discrimination against Israel is known extends from the secretary general to lower echelons of the United Nations. See:

http://elderofziyon.blogspot.com.au/2013/11/un-interpreter-accidentally-tellsworld.html\#.UofVPj-OYTJ. (accessed 23 July 2014).
}

This link also offers the opportunity to witness a real-time vote taken on a resolution against Israel. 
and Muslim countries aside) do not have a tradition of antisemitism. Antisemitism can enter the decoy-voting model through the prediction that the decoy is chosen to maximize majorities in decoy resolutions. If another country could be found against which a greater number of governments outside the autocratic bloc were prepared to vote - or to vote against more of the time - that alternative country would be the decoy. Israel is however revealed to be an effective decoy, with opposition to decoy resolutions reduced in 80 percent of resolutions to the small voting bloc of Australia, Canada, the United States, and the Pacific Island states noted above. A tradition of prejudice could be an influence on the willingness of some governments of European and Latin American countries to participate in decoy voting. ${ }^{39}$

\section{Concluding remarks}

Voting in the United Nations General Assembly has been extensively studied. ${ }^{40}$ We have added to the past studies by placing voting in the General Assembly in a context of expres-

\footnotetext{
${ }^{39}$ The literature on antisemitism in Europe includes Wistrich (1991) and Carmichael (1992). For an overview from a behavioral perspective, see Hillman (2013). Voigtlander and Voth (2012) report evidence of remarkable historical regional persistence in Europe of antisemitism. Gerstenfeld (2013) reports survey evidence that some 60 percent of the population of Europe harbored "extreme antiIsraeli and/or anti-Jewish attitudes." For religiously conservative elites and populations in European countries, the establishment of the modern state of Israel in 1948 contradicted the doctrine of supersession. The reborn Jewish state has also been contrary to the ideology of socialism; following on from Karl Marx's condemnation of the Jews (Marx 1844) as the harbingers of capitalism (with Marx himself having been descended from Jews), socialist parties in Europe have often adopted prejudicial views of the Jewish state. In Latin America, the origins of antisemitism began with European settlement through transfer from the Spanish and Portuguese Inquisition (Kohut 1895).

${ }^{40}$ Considerable attention has been directed to investigating vote buying: see studies by Wittkopf (1973), Kuziemko and Werker (2006), Dreher, Nunnenkamp and Thiele (2008), Dreher, Sturm and Vreeland (2009), and Dreher and Sturm (2012). General Assembly voting with regard to human rights has been studied by Boockmann and Dreher (2011). The United States has figured prominently in conclusions about voting patterns: Voeten (2000) found that countries could be distinguished accord-
} 
sive behavior as suggested by visible voting on non-binding resolutions. Data on all United Nations General Assembly resolutions between January 1990 and June 2013 on which votes were taken has revealed an extraordinary preoccupation with criticism of one country, Israel. We have confirmed that the focus on criticism of Israel reflects discrimination. To explain the discrimination, we have presented a decoy-voting model that includes autocratic vanity and esteem and a Schelling focal point for deflection of criticism. Traditional prejudice enters insofar as the decoy is chosen to maximize supermajorities in decoy resolutions.

The state of Israel has had a central role in our study - as a consequence of the revealed preoccupation with Israel in United Nations General Assembly voting. The primary conclusions of our study should not be seen, however, as being in particular about Israel. Our conclusions are more general and concern political culture, as reflected in the presumptions and ethical standards according to which governments and politicians conduct themselves (see Hillman and Swank 2000).

We have noted that intimidation has been observed in the United Nations. Data sources provide no basis for criticism of Canada on human-rights or other related grounds but, after reaffirmation that it would not participate in decoy voting, Canada was accused by autocracies - of human rights violations that included child sexual exploitation, racism and discrimination against indigenous peoples, and torture and other cruelty toward its citizens. ${ }^{41}$

\footnotetext{
ing to whether they voted consistently with or against the United States; Dreher and Jensen (2013) concluded that changes in leadership of UN members' governments tend to be accompanied by a change to voting with the United States. Among OECD countries, left-wing governments have been less likely to vote in line with the United States (Potrafke 2009).

${ }^{41}$ In more detail, the accusations were, by the representative of Iran, of "violations of human rights by the Canadian government, particularly with regard to child sexual exploitation and trafficking, the
} 
The case of the accusations against Canada, in conjunction with the autocratic political institutions of the countries making the accusations, substantiate that the issue in the United Nations is not the treatment of one particular country. Majority political culture in the United Nations allows and sustains decoy voting but also makes any democracy vulnerable to the accusation of behavior that is precisely that of the accusing autocratic majority.

Acknowledgements: We thank Carl Maier and Jakob Müller for their dedication in assisting in compiling data from the many UN resolutions. For comments, we thank Michael Beenstock, Paula Castro, Dror Goldberg, Francesco Forte, Arthur Fishman, Raphael Franck, Carsten Hefeker, Simon Hug, Jean-Dominique Lafay, Pierre Kopp, Ngo Van Long, Mickaël Melki, Kwang Ng, David Schmeidler, George Tridimas, Heinrich Ursprung, and Avi Weiss. We have also benefitted from the advice of anonymous referees and the editor. Earlier results from this research project were presented in Israel at Bar-Ilan University, the Herzliya Interdisciplinary Center, and Ben-Gurion University; in Europe, at the 2011 conference on The Political Economy of International Organizations in Zurich, the 2011 Meetings of the

right to food, discriminatory law and regulation against indigenous people and minority groups including Muslim and African communities". The representative of Cuba accused Canada of "racism and xenophobia." The criticisms of Canada by the representative of North Korea were: "We have serious concerns about continued violation of the right to peaceful assembly and freedom of expression, torture and other ill-treatment, racism and xenophobia." The representative of China stated: "We are concerned by the wide-spread racial discrimination in Canada." The representative of Egypt stated: "We are alarmed by several instances of racial profiling in law-enforcement action and racial discrimination in employment." The representative of Pakistan stated: "The increased poverty and unemployment rate among immigrant communities is a manifestation of racial discrimination." The accusations against Canada by the representative of Russia claimed human-rights violations in demonstrations: "Human rights defenders are alarmed by police actions of torture and cruelty against peaceful demonstrators." Source: the debate on the UN quadrennial review of Canada's human rights record (April 26, 2013). See

http:/ / www.unwatch.org/site/apps/nlnet/content2.aspx?c=bdKKISNqEmG\&b=1316871\&ct=13106 $\underline{277}$ (accessed 21 June 2013). 
European Public Choice Society in Rennes, the 2011 Meetings of the European Association of Law and Economics in Hamburg, and in seminars at the University of Tübingen, the University of Rome La Sapienza, and the University of Paris I (Sorbonne-Panthéon); in the U.S. at the 2011 Meetings of the Public Choice Society in San Antonio and in seminars at the University of Miami, the University of Florida, and the University of West Virginia; and in Australia at the 2012 conference of the Australasian Public Choice Society in Hobart and in seminars at the University of Wollongong and Monash University. We thank participants for their views and observations.

\section{References}

Akerlof, G.A., \& Kranton, R.E. (2010). Identity economics: How our identities shape our work, wages, and well-being. Princeton, NJ: Princeton University Press.

Alesina, A., Devleeschauwer, A., Easterly, W., Kurlat, S., \& Wacziarg, R. (2003). Fractionalization. Journal of Economic Growth, 8(2), 155-194.

Annan, K. (2000). 'We the Peoples': The role of the United Nations, 21st century. New York, NY: United Nations.

Ban, K.-m. (2013). Building a better future for all: Selected speeches of United Nations SecretaryGeneral Ban Ki-moon, 2007-2012. New York, NY: United Nations.

Boockmann, B., \& Dreher, A. (2011). Do human rights offenders oppose human rights resolutions in the United Nations? Public Choice, 146(3-4), 443-467.

Borooah, V.K., \& Paldam, M. (2007). Why is the world short of democracy?: A cross-country analysis of barriers to representative government. European Journal of Political Economy, 23(3), 582-604.

Brennan, G., \& Brooks, M. (2013). Expressive voting. In W. Shughart II, L. Razzolini, \& M. Reksulak (Eds.), The Elgar Companion to Public Choice (2nd ed., pp. 111-126). Cheltenham, U.K.: Edward Elgar Publishing.

Brennan, G., \& Hamlin, A. (2000). Democratic devices and desires. Cambridge, U.K.: Cambridge University Press.

Brennan, G., \& Pettit, P. (2004). The economy of esteem: An essay on civil and political society. Oxford, U.K.: Oxford University Press.

Cingranelli, D.L., \& Richards, D.L. (2010). The Cingranelli and Richards (CIRI) Human Rights Data Project. Human Rights Quarterly, 32(2), 401-424.

Carmichael, J. (1992). The Satanizing of the Jews: Origin and development of mystical antisemitism (1st ed). New York, NY: Fromm International Publishing Corporation.

Carothers, T. (2002). The end of the transition paradigm. Journal of Democracy, 13(1), 5-21.

Demick, B. (2009). Nothing to envy: Ordinary lives in North Korea. New York, NY: Spiegel \& Grau.

Dixit, A., Grossman, G.M., \& Gul, F. (2000). The dynamics of political compromise. Journal of Political Economy, 108(3), 531-568.

Donnelly, J. (1988). Human rights in the United Nations: 1955-85: The question of bias. International Studies Quarterly 32(3), 275-303.

Dreher, A., \& Jensen, N.M. (2013). Country or leader? Political change and UN General Assembly voting. European Journal of Political Economy, 29(1), 183-196. 
Dreher, A., Nunnenkamp, P., \& Thiele, R. (2008). Does US aid buy UN General Assembly votes? A disaggregated analysis. Public Choice, 136(1-2), 139-164.

Dreher, A., \& Sturm, J.-E. (2012). Do the IMF and the World Bank influence voting in the UN General Assembly? Public Choice, 151(1-2), 363-397.

Dreher, A., Sturm, J.-E., \& Vreeland, J. R. (2009). Development aid and international politics: Does membership on the UN Security Council influence World Bank decisions? Journal of Development Economics, 88(1), 1-18.

Easterly, W. (2011). Benevolent autocrats. http:/ / williameasterly.files.word press.com/2011/05/benevolent-autocrats-easterly2nd-draft.pdf. Accessed 4 March 2014.

Engelen, B. (2006). Solving the paradox: The expressive rationality of the decision to vote. Rationality and Society, 18(4), 419-441.

Fasulo, L.M. (2004). An insider's guide to the UN. New Haven, CT: Yale University Press.

Fish, M.S. (2002). Islam and authoritarianism. World Politics, 55(1), 4-37.

Forster, A., \& Epstein, B. R. (1974). The new anti-Semitism. New York, NY: McGraw-Hill.

Gerstenfeld, M. (2013). Demonizing Israel and the Jews. New York, NY: RVP Press.

Glazer, A. (2008). Voting to anger and to please others. Public Choice, 134(3-4), 247-254.

Gupta, S., Clements, B., Bhattacharya, R., \& Chakravarti, S. (2004). Fiscal consequences of armed conflict and terrorism in low- and middle-income countries. European Journal of Political Economy, 20(2), 403-421.

Gupta, S., Mello, L. de, \& Sharan, R. (2001). Corruption and military spending. European Journal of Political Economy, 17(4), 749-777.

Hamlin, A., \& Jennings, C. (2011). Expressive political behaviour: foundations, scope and implications. British Journal of Political Science, 41(3), 645-670.

Herne, K. (1997). Decoy alternatives in policy choices: asymmetric domination and compromise effects. European Journal of Political Economy, 13(3), 575-589.

Hillman, A.L. (2010). Expressive behavior in economics and politics. European Journal of Political Economy, 26(4), 403-418.

Hillman, A.L. (2013). Economic and behavioral foundations of prejudice. In C.S. Small (Ed.), Global antisemitism: A crisis of modernity (pp. 51-67). Leiden, Netherlands, and Boston, MA: Martinus Nijhoff Publishers.

Hillman, A.L., \& Swank, O. (2000). Why political culture should be in the lexicon of economics. European Journal of Political Economy, 16(1), 1-4.

Hillman, A.L., \& Potrafke, N. (2014). The UN Goldstone Report and retraction: An empirical investigation. Working paper, Bar-Ilan University, Israel.

Horowitz, D.L. (1985). Ethnic groups in conflict. , Berkeley, CA: University of California Press.

Hovet, T. (1960). Bloc politics in the United Nations. Cambridge, MA: Harvard University Press.

Hug, S. (2012). What is in a vote? Paper presented at the Annual Meeting of the American Political Science Association, New Orleans, August 30 - September 2. file:///C:/Users/Alex\%20Privat/Desktop/SSRN-id2106672.pdf. Accessed 4 March 2014.

Hug, S., \& Lukács, B. (2014). Preferences or blocs? Voting in the United Nations Human Rights Council. Review of International Organizations, 9(1), 83-106.

Iida, K. (1988). Third World solidarity: the Group of 77 in the UN General Assembly. International Organization, 42(2), 375-395.

Judaken, J. (2008). So what's new? Rethinking the 'new antisemitism' in a global age. Patterns of Prejudice, 42(4-5), 531-560.

Kim, S. Y., \& Russett, B. (1996). The new politics of voting alignments in the United Nations General Assembly. International Organization, 50(4), 629-652. 
Kohut, G. A. (1895). Jewish martyrs of the inquisition in South America. Baltimore, MD: Friedenwald.

Kuziemko, I., \& Werker, E. (2006). How much is a seat on the Security Council worth? Foreign aid and bribery at the United Nations. Journal of Political Economy, 114(5), 905-930.

Martin, B.K. (2006). Under the loving care of the fatherly leader: North Korea and the Kim Dynasty (1st edn). New York, NY: St. Martin's Press.

Marx, K. (1844). Zur Judenfrage. In A. Ruge \& K. Marx (Eds.), Deutsch-Französische Jahrbücher (pp. 182-214). Paris, France: Bureau der Jahrbücher.

Neumayer, E. (2013). Do governments mean business when they derogate? Human rights violations during notified states of emergency. Review of International Organizations, 8(1), $1-31$.

Potrafke, N. (2009). Does government ideology influence political alignment with the US? An empirical analysis of UN General Assembly voting. Review of International Organizations 4(3), 245-268.

Potrafke, N. (2012). Islam and democracy. Public Choice, 151(1-2), 185-192.

Potrafke, N. (2013). Democracy and countries with Muslim majorities: a reply and update. Public Choice, 154(3-4), 323-332.

Rosen, S.J. (2010). Will Obama use his veto? Commentary Magazine, 130, 29-33.

Rowley, C.K. (2000). Political culture and economic performance in sub-Saharan Africa. European Journal of Political Economy, 16(1), 133-158.

Schelling, T. (1978). Micromotives and macrobehavior. New York, NY: Norton.

Tullock, G. (1971). The charity of the uncharitable. Economic Inquiry, 9(4), 379-392.

United Nations General Assembly (2000). United Nations Millennium Declaration, resolution adopted by the General Assembly. A/RES/55/2. New York, NY: United Nations. http://www.un.org/millennium/declaration/ares552e.htm. Accessed 5 March 2014.

United Nations Human Rights Council (2009). Human rights in Palestine and other occupied Arab territories: report of the United Nations Fact-Finding Mission on the Gaza Conflict. A/HR/12/48. New York, NY: United Nations. http://www2.ohchr.org/english/bodies/hrcouncil/docs/12session/A-HRC-12-48.pdf. Accessed 5 March 2014.

United Nations Millennium Project (2005). Investing in development: a practical plan to achieve the Millennium Development Goals. New York, NY: United Nations.

http://www.unmillenniumproject.org/documents/MainReportComplete-lowres.pdf. Accessed 5 March 2014.

Vaubel, R., \& Willett, T.D. (1991). The political economy of international organizations: A public choice approach (The Political economy of global interdependence). Boulder, CO: Westview Press.

Voeten, E. (2000). Clashes in the Assembly. International Organization, 54(2), 185-215.

Voigtlander, N., \& Voth, H.-J. (2012). Persecution perpetuated: the medieval origins of antisemitic violence in Nazi Germany. The Quarterly Journal of Economics, 127(3), 1339-1392.

Wistrich, R.S. (1991). Antisemitism: The longest hatred. New York, NY: Pantheon Books.

Wittkopf, E.R. (1973). Foreign aid and United Nations votes: A comparative study. American Political Science Review, 67(3), 868-888. 
Table 1: UNGA resolutions referring to countries, January 1990 to June 2013

\begin{tabular}{|c|c|c|c|c|}
\hline Country & $\begin{array}{l}\text { Number of } \\
\text { resolutions } \\
\text { in which the } \\
\text { country is } \\
\text { mentioned }\end{array}$ & $\begin{array}{l}\text { Number of } \\
\text { resolutions } \\
\text { in which } \\
\text { the country } \\
\text { is criticized }\end{array}$ & $\begin{array}{l}\text { Number of } \\
\text { resolutions } \\
\text { in which } \\
\text { the country } \\
\text { is praised }\end{array}$ & $\begin{array}{c}\text { Average } \\
\text { support for } \\
\text { resolutions } \\
\text { criticizing } \\
\text { (Share of } \\
\text { Yes votes) }\end{array}$ \\
\hline Israel & 480 & 422 & 27 & 87.4 \\
\hline Palestine & 438 & 29 & 55 & 91.4 \\
\hline United States of America & 145 & 39 & 105 & 87.6 \\
\hline Russia (including former USSR) & 123 & 16 & 103 & 84.6 \\
\hline Lebanon & 101 & 0 & 27 & \\
\hline Syria (without Syrian Golan) & 70 & 5 & 18 & 72.6 \\
\hline South Africa & 67 & 59 & 9 & 75.5 \\
\hline Dem. People's Republic of Korea & 39 & 38 & 0 & 87.2 \\
\hline Jordan & 35 & 0 & 22 & \\
\hline Iraq & 31 & 22 & 4 & 80.8 \\
\hline Belarus & 30 & 2 & 27 & 40.5 \\
\hline Ukraine & 29 & 0 & 27 & \\
\hline Kazakhstan & 28 & 0 & 27 & \\
\hline Cuba & 27 & 6 & 2 & 41.4 \\
\hline Yugoslavia, F.R. & 23 & 16 & 4 & 77.2 \\
\hline Iran & 22 & 21 & 12 & 45.4 \\
\hline United Kingdom & 19 & 4 & 16 & 95.4 \\
\hline France & 19 & 5 & 7 & 80.0 \\
\hline Angola & 18 & 0 & 12 & \\
\hline Bosnia & 17 & 7 & 5 & 83.7 \\
\hline New Zealand & 15 & 0 & 13 & \\
\hline Kuwait & 15 & 0 & 0 & \\
\hline Croatia & 15 & 6 & 4 & 86.5 \\
\hline Sudan & 12 & 10 & 3 & 58.1 \\
\hline Dem. Republic of the Congo & 11 & 10 & 10 & 63.4 \\
\hline Namibia & 11 & 0 & 5 & - \\
\hline
\end{tabular}


Table 2: Israel 1990 to 2012

\begin{tabular}{|c|c|c|c|c|c|c|}
\hline (1) & (2) & (3) & (4) & (5) & (6) & (7) \\
\hline \multirow[t]{2}{*}{ Year } & \multicolumn{2}{|c|}{ Critical resolutions } & \multicolumn{2}{|c|}{$\begin{array}{l}\text { Battle-related } \\
\text { Fatalities }\end{array}$} & \multirow{2}{*}{$\begin{array}{c}\text { Physical } \\
\text { Integrity } \\
\text { Rights } \\
\text { Index }\end{array}$} & \multirow{2}{*}{$\begin{array}{c}\text { New } \\
\text { Empow- } \\
\text { erment } \\
\text { Rights } \\
\text { Index }\end{array}$} \\
\hline & $\begin{array}{l}\text { Absolute } \\
\text { Number* }\end{array}$ & $\begin{array}{c}\% \text { of all } \\
\text { critical reso- } \\
\text { lutions* }\end{array}$ & $\begin{array}{l}\text { Absolute } \\
\text { Number* }\end{array}$ & $\begin{array}{c}\text { per Resolu- } \\
\text { tion* } \\
(4) /(2)\end{array}$ & & \\
\hline 1990 & 26 & 51.0 & 71 & 2.7 & 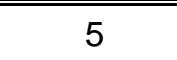 & 10 \\
\hline 1991 & 25 & 58.1 & 56 & 2.2 & 3 & 9 \\
\hline 1992 & 24 & 55.8 & 120 & 5 & 3 & 8 \\
\hline 1993 & 17 & 58.6 & 171 & 10.1 & 4 & 8 \\
\hline 1994 & 12 & 57.1 & 126 & 10.5 & 2 & 8 \\
\hline 1995 & 14 & 46.7 & 108 & 7.7 & 4 & 7 \\
\hline 1996 & 17 & 65.4 & 161 & 9.5 & 5 & 9 \\
\hline 1997 & 16 & 61.5 & 82 & 5.1 & 3 & 8 \\
\hline 1998 & 17 & 70.8 & 54 & 3.2 & 4 & 8 \\
\hline 1999 & 16 & 69.6 & 41 & 2.6 & 3 & 8 \\
\hline 2000 & 15 & 71.4 & 77 & 5.1 & 3 & 9 \\
\hline 2001 & 17 & 77.3 & 218 & 12.8 & 2 & 9 \\
\hline 2002 & 18 & 72 & 413 & 22.9 & 2 & 9 \\
\hline 2003 & 21 & 77.8 & 307 & 14.6 & 2 & 10 \\
\hline 2004 & 18 & 78.3 & 361 & 20.1 & 2 & 9 \\
\hline 2005 & 19 & 76 & 119 & 6.3 & 2 & 7 \\
\hline 2006 & 22 & 73.3 & 1149 & 52.2 & 2 & 7 \\
\hline 2007 & 18 & 66.7 & 272 & 15.1 & 2 & 5 \\
\hline 2008 & 18 & 72 & 665 & 36.9 & 3 & 1 \\
\hline 2009 & 20 & 74.1 & 682 & 34.1 & 2 & 3 \\
\hline 2010 & 18 & 75 & 27 & 1.5 & 2 & 3 \\
\hline 2011 & 17 & 58.6 & 56 & 3.3 & 2 & 4 \\
\hline 2012 & 17 & 68 & 64 & 3.8 & - & - \\
\hline Mean & 18.3 & 66.7 & 234.8 & 12.5 & 2.8 & 7.2 \\
\hline Total & 422 & 65.3 & 5400 & 12.8 & - & - \\
\hline
\end{tabular}

*All values corresponding to the specific year 
Table 3: South Africa 1990 to 2012

\begin{tabular}{|c|c|c|c|c|c|c|}
\hline (1) & (2) & (3) & (4) & (5) & (6) & (7) \\
\hline \multirow[t]{2}{*}{ Year } & \multicolumn{2}{|c|}{ Critical resolutions } & \multicolumn{2}{|c|}{$\begin{array}{l}\text { Battle-related } \\
\text { Fatalities }\end{array}$} & \multirow{2}{*}{$\begin{array}{c}\text { Physical } \\
\text { Integrity } \\
\text { Rights } \\
\text { Index }\end{array}$} & \multirow{2}{*}{$\begin{array}{c}\text { New } \\
\text { Empow } \\
\text { erment } \\
\text { Rights } \\
\text { Index }\end{array}$} \\
\hline & $\begin{array}{l}\text { Absolute } \\
\text { Number* }\end{array}$ & $\begin{array}{c}\% \text { of all } \\
\text { critical reso- } \\
\text { lutions }\end{array}$ & $\begin{array}{l}\text { Absolute } \\
\text { Number* }\end{array}$ & $\begin{array}{c}\text { per Resolu- } \\
\text { tion* } \\
(4) /(2)\end{array}$ & & \\
\hline 1990 & 24 & 47.1 & - & - & 2 & 4 \\
\hline 1991 & 17 & 39.5 & - & - & 2 & 4 \\
\hline 1992 & 13 & 30.2 & - & - & 2 & 7 \\
\hline 1993 & 5 & 17.2 & - & - & 1 & 8 \\
\hline 1994 & 0 & 0 & - & - & 2 & 11 \\
\hline 1995 & 0 & 0 & - & - & 5 & 12 \\
\hline 1996 & 0 & 0 & - & - & 5 & 13 \\
\hline 1997 & 0 & 0 & - & - & 3 & 11 \\
\hline 1998 & 0 & 0 & - & - & 4 & 13 \\
\hline 1999 & 0 & 0 & - & - & 4 & 13 \\
\hline 2000 & 0 & 0 & - & - & 4 & 13 \\
\hline 2001 & 0 & 0 & - & - & 5 & 13 \\
\hline 2002 & 0 & 0 & - & - & 5 & 12 \\
\hline 2003 & 0 & 0 & - & - & 4 & 12 \\
\hline 2004 & 0 & 0 & - & - & 5 & 12 \\
\hline 2005 & 0 & 0 & - & - & 4 & 11 \\
\hline 2006 & 0 & 0 & - & - & 4 & 11 \\
\hline 2007 & 0 & 0 & - & - & 2 & 10 \\
\hline 2008 & 0 & 0 & - & - & 2 & 10 \\
\hline 2009 & 0 & 0 & - & - & 2 & 10 \\
\hline 2010 & 0 & 0 & - & - & 2 & 11 \\
\hline 2011 & 0 & 0 & - & - & 4 & 11 \\
\hline 2012 & 0 & 0 & - & - & - & - \\
\hline Mean & 2.6 & 5.8 & - & - & 3.3 & 10.5 \\
\hline Total & 59 & 9.1 & - & - & - & - \\
\hline
\end{tabular}

*All values corresponding to the specific year 
Table 4: Democratic People's Republic of Korea 1990 to 2012

\begin{tabular}{|c|c|c|c|c|c|c|}
\hline (1) & (2) & (3) & (4) & (5) & (6) & (7) \\
\hline \multirow[t]{2}{*}{ Year } & \multicolumn{2}{|c|}{ Critical resolutions } & \multicolumn{2}{|c|}{$\begin{array}{l}\text { Battle-related } \\
\text { Fatalities }\end{array}$} & \multirow{2}{*}{$\begin{array}{c}\text { Physical } \\
\text { Integrity } \\
\text { Rights } \\
\text { Index }\end{array}$} & \multirow{2}{*}{$\begin{array}{c}\text { New } \\
\text { Empow- } \\
\text { erment } \\
\text { Rights } \\
\text { Index }\end{array}$} \\
\hline & $\begin{array}{l}\text { Absolute } \\
\text { Number* }\end{array}$ & $\begin{array}{c}\% \text { of all } \\
\text { critical reso- } \\
\text { lutions* }\end{array}$ & $\begin{array}{l}\text { Absolute } \\
\text { Number* }\end{array}$ & $\begin{array}{c}\text { per Resolu- } \\
\text { tion* } \\
(4) /(2)\end{array}$ & & \\
\hline 1990 & 0 & 0 & - & - & - & 1 \\
\hline 1991 & 0 & 0 & - & - & - & 0 \\
\hline 1992 & 0 & 0 & - & - & - & 0 \\
\hline 1993 & 1 & 3.4 & - & - & - & 1 \\
\hline 1994 & 1 & 4.8 & - & - & - & 0 \\
\hline 1995 & 1 & 3.3 & - & - & 3 & 0 \\
\hline 1996 & 1 & 3.8 & - & - & 0 & 0 \\
\hline 1997 & 1 & 3.8 & - & - & 0 & 0 \\
\hline 1998 & 1 & 4.2 & - & - & 0 & 0 \\
\hline 1999 & 1 & 4.3 & - & - & 0 & 0 \\
\hline 2000 & 0 & 0 & - & - & 0 & 0 \\
\hline 2001 & 1 & 4.5 & - & - & 0 & 0 \\
\hline 2002 & 1 & 4.0 & - & - & 0 & 0 \\
\hline 2003 & 2 & 7.4 & - & - & 0 & 0 \\
\hline 2004 & 1 & 4.3 & - & - & 0 & 0 \\
\hline 2005 & 2 & 8.0 & - & - & 0 & 0 \\
\hline 2006 & 5 & 16.7 & - & - & 0 & 0 \\
\hline 2007 & 4 & 14.8 & - & - & 0 & 0 \\
\hline 2008 & 4 & 16.0 & - & - & 0 & 0 \\
\hline 2009 & 3 & 11.1 & - & - & 0 & 0 \\
\hline 2010 & 3 & 12.5 & - & - & 0 & 0 \\
\hline 2011 & 3 & 10.3 & - & - & 1 & 0 \\
\hline 2012 & 2 & 8.0 & - & - & - & - \\
\hline Mean & 1.7 & 6.3 & - & - & 0.2 & 0.1 \\
\hline Total & 38 & 5.9 & - & - & - & - \\
\hline
\end{tabular}

*All values corresponding to the specific year 
Table 5: United States of America 1990 to 2012

\begin{tabular}{|c|c|c|c|c|c|c|}
\hline (1) & (2) & (3) & (4) & (5) & (6) & (7) \\
\hline \multirow[t]{2}{*}{ Year } & \multicolumn{2}{|c|}{ Critical resolutions } & \multicolumn{2}{|c|}{$\begin{array}{l}\text { Battle-related } \\
\text { Fatalities }\end{array}$} & \multirow{2}{*}{$\begin{array}{c}\text { Physical } \\
\text { Integrity } \\
\text { Rights } \\
\text { Index }\end{array}$} & \multirow{2}{*}{$\begin{array}{c}\text { New } \\
\text { Empow- } \\
\text { erment } \\
\text { Rights } \\
\text { Index }\end{array}$} \\
\hline & $\begin{array}{l}\text { Absolute } \\
\text { Number* }\end{array}$ & $\begin{array}{c}\% \text { of all } \\
\text { critical reso- } \\
\text { lutions* }\end{array}$ & $\begin{array}{l}\text { Absolute } \\
\text { Number* }\end{array}$ & $\begin{array}{c}\text { per Resolu- } \\
\text { tion* } \\
(4) /(2)\end{array}$ & & \\
\hline 1990 & 5 & 9.8 & - & - & 8 & 12 \\
\hline 1991 & 1 & 2.3 & - & - & 7 & 12 \\
\hline 1992 & 3 & 7.0 & - & - & 7 & 12 \\
\hline 1993 & 2 & 6.9 & - & - & 7 & 12 \\
\hline 1994 & 1 & 4.8 & - & - & 7 & 12 \\
\hline 1995 & 4 & 13.3 & - & - & 7 & 12 \\
\hline 1996 & 1 & 3.8 & - & - & 7 & 12 \\
\hline 1997 & 1 & 3.8 & - & - & 7 & 12 \\
\hline 1998 & 2 & 8.3 & - & - & 7 & 12 \\
\hline 1999 & 1 & 4.3 & - & - & 7 & 12 \\
\hline 2000 & 1 & 4.8 & - & - & 7 & 12 \\
\hline 2001 & 1 & 4.5 & 1585 & 1585 & 5 & 12 \\
\hline 2002 & 2 & 8.0 & 710 & 355 & 6 & 12 \\
\hline 2003 & 3 & 11.1 & 8202 & 2734 & 6 & 12 \\
\hline 2004 & 2 & 8.7 & 320 & 160 & 4 & 12 \\
\hline 2005 & 1 & 4.0 & 100 & 100 & 4 & 12 \\
\hline 2006 & 1 & 3.3 & 191 & 191 & 4 & 12 \\
\hline 2007 & 1 & 3.7 & 153 & 153 & 5 & 12 \\
\hline 2008 & 1 & 4.0 & 182 & 182 & 6 & 12 \\
\hline 2009 & 2 & 7.4 & 391 & 195.5 & 5 & 12 \\
\hline 2010 & 1 & 4.2 & 269 & 269 & 6 & 12 \\
\hline 2011 & 1 & 3.4 & 190 & 190 & 6 & 11 \\
\hline 2012 & 1 & 4.0 & 221 & 221 & - & - \\
\hline Mean & 2 & 5.9 & 1043 & 528.0 & 6.1 & 12.0 \\
\hline Total & 39 & 6.0 & 12514 & 320.9 & - & - \\
\hline
\end{tabular}

*All values corresponding to the specific year 
Table 6: Iran 1990 to 2012

\begin{tabular}{|c|c|c|c|c|c|c|}
\hline (1) & (2) & (3) & (4) & (5) & (6) & (7) \\
\hline \multirow[t]{2}{*}{ Year } & \multicolumn{2}{|c|}{ Critical resolutions } & \multicolumn{2}{|c|}{$\begin{array}{l}\text { Battle-related } \\
\text { Fatalities }\end{array}$} & \multirow{2}{*}{$\begin{array}{c}\text { Physical } \\
\text { Integrity } \\
\text { Rights } \\
\text { Index }\end{array}$} & \multirow{2}{*}{$\begin{array}{c}\text { New } \\
\text { Empow } \\
\text { erment } \\
\text { Rights } \\
\text { Index }\end{array}$} \\
\hline & $\begin{array}{l}\text { Absolute } \\
\text { Number* }\end{array}$ & $\begin{array}{l}\% \text { of all } \\
\text { critical reso- } \\
\text { lutions* }\end{array}$ & $\begin{array}{l}\text { Absolute } \\
\text { Number* }\end{array}$ & $\begin{array}{c}\text { per Resolu- } \\
\text { tion* } \\
(4) /(2)\end{array}$ & & \\
\hline 1990 & 0 & 0 & 31 & - & 1 & 3 \\
\hline 1991 & 0 & 0 & 45 & - & 1 & 2 \\
\hline 1992 & 1 & 2.3 & 25 & 25 & 3 & 3 \\
\hline 1993 & 1 & 3.4 & 186 & 186 & 1 & 3 \\
\hline 1994 & 1 & 4.8 & - & - & 3 & 2 \\
\hline 1995 & 1 & 3.3 & - & - & 2 & 2 \\
\hline 1996 & 1 & 3.8 & 27 & 27 & 2 & 2 \\
\hline 1997 & 1 & 3.8 & 38 & 38 & 1 & 2 \\
\hline 1998 & 1 & 4.2 & - & - & 1 & 2 \\
\hline 1999 & 1 & 4.3 & 28 & 28 & 0 & 2 \\
\hline 2000 & 1 & 4.8 & 40 & 40 & 1 & 1 \\
\hline 2001 & 1 & 4.5 & 119 & 119 & 1 & 1 \\
\hline 2002 & 0 & 0 & - & - & 1 & 1 \\
\hline 2003 & 1 & 3.7 & - & - & 2 & 1 \\
\hline 2004 & 1 & 4.3 & - & - & - & 1 \\
\hline 2005 & 1 & 4 & 28 & 28 & 1 & 1 \\
\hline 2006 & 1 & 3.3 & 57 & 57 & - & 1 \\
\hline 2007 & 1 & 3.7 & 72 & 72 & 1 & 0 \\
\hline 2008 & 1 & 4 & 121 & 121 & 0 & 0 \\
\hline 2009 & 1 & 3.7 & 133 & 133 & 0 & 0 \\
\hline 2010 & 1 & 4.2 & 74 & 74 & 0 & 0 \\
\hline 2011 & 2 & 6.9 & 219 & 109.5 & 0 & 0 \\
\hline 2012 & 1 & 4 & - & - & - & - \\
\hline Mean & 0.9 & 3.5 & 77.7 & 75.5 & 1.1 & 1.4 \\
\hline Total & 21 & 3.3 & 1243 & 59.2 & - & - \\
\hline
\end{tabular}

*All values corresponding to the specific year 
Table 7: Iraq 1990 to 2012

\begin{tabular}{|c|c|c|c|c|c|c|}
\hline (1) & (2) & (3) & (4) & (5) & (6) & (7) \\
\hline \multirow[t]{2}{*}{ Year } & \multicolumn{2}{|c|}{ Critical resolutions } & \multicolumn{2}{|c|}{$\begin{array}{l}\text { Battle-related } \\
\text { Fatalities }\end{array}$} & \multirow{2}{*}{$\begin{array}{c}\text { Physical } \\
\text { Integrity } \\
\text { Rights } \\
\text { Index }\end{array}$} & \multirow{2}{*}{$\begin{array}{c}\text { New } \\
\text { Empow- } \\
\text { erment } \\
\text { Rights } \\
\text { Index }\end{array}$} \\
\hline & $\begin{array}{l}\text { Absolute } \\
\text { Number* }\end{array}$ & $\begin{array}{c}\% \text { of all } \\
\text { critical reso- } \\
\text { lutions* }\end{array}$ & $\begin{array}{l}\text { Absolute } \\
\text { Number* }\end{array}$ & $\begin{array}{c}\text { per Resolu- } \\
\text { tion* }^{*} \\
(4) /(2)\end{array}$ & & \\
\hline 1990 & 1 & 2.0 & 1152 & 1152 & 0 & 2 \\
\hline 1991 & 3 & 7.0 & 22571 & 7523.7 & 0 & 0 \\
\hline 1992 & 2 & 4.7 & 306 & 153 & 0 & 0 \\
\hline 1993 & 2 & 6.9 & 75 & 37.5 & 0 & 0 \\
\hline 1994 & 1 & 4.8 & 25 & 25 & 2 & 0 \\
\hline 1995 & 1 & 3.3 & 587 & 587 & 3 & 0 \\
\hline 1996 & 1 & 3.8 & 398 & 398 & 0 & 0 \\
\hline 1997 & 2 & 7.7 & - & - & 0 & 0 \\
\hline 1998 & 2 & 8.3 & - & - & 0 & 0 \\
\hline 1999 & 2 & 8.7 & - & - & 0 & 0 \\
\hline 2000 & 1 & 4.8 & - & - & 0 & 0 \\
\hline 2001 & 1 & 4.5 & - & - & 0 & 0 \\
\hline 2002 & 1 & 4 & - & - & 0 & 0 \\
\hline 2003 & 1 & 3.7 & 8202 & 8202 & - & - \\
\hline 2004 & 1 & 4.3 & 3499 & 3499 & - & - \\
\hline 2005 & 0 & 0 & 2364 & - & 1 & 4 \\
\hline 2006 & 0 & 0 & 3931 & - & 1 & 4 \\
\hline 2007 & 0 & 0 & 1943 & - & 0 & 4 \\
\hline 2008 & 0 & 0 & 2090 & - & 1 & 1 \\
\hline 2009 & 0 & 0 & 1036 & - & 3 & 3 \\
\hline 2010 & 0 & 0 & 1015 & - & 3 & 3 \\
\hline 2011 & 0 & 0 & 861 & - & 3 & 2 \\
\hline 2012 & 0 & 0 & 565 & - & - & - \\
\hline Mean & 1.0 & 3.4 & 2977.6 & 2397.5 & 0.9 & 1.2 \\
\hline Total & 22 & 3.4 & 50620 & 2300.9 & - & - \\
\hline
\end{tabular}

*All values corresponding to the specific year 
Table 8: Repeated votes on a resolution on "Applicability of the Geneva Convention"

\begin{tabular}{clcccc}
\hline Year & UN vote & Against & Abstain & In favor & Not voting \\
\hline 1996 & A/RES/51/132 & 2 & 3 & 156 & 31 \\
1997 & A/RES/52/65 & 2 & 3 & 156 & 31 \\
1998 & A/RES/53/54 & 2 & 2 & 155 & 33 \\
1999 & A/RES/54/77 & 2 & 1 & 154 & 35 \\
2000 & A/RES/55/131 & 2 & 2 & 152 & 36 \\
2001 & A/RES/56/60 & 4 & 2 & 148 & 38 \\
2002 & A/RES/57/125 & 6 & 3 & 155 & 28 \\
2003 & A/RES/58/97 & 6 & 4 & 164 & 18 \\
2004 & A/RES/59/122 & 7 & 11 & 160 & 14 \\
2005 & A/RES/60/105 & 6 & 7 & 158 & 21 \\
2006 & A/RES/61/117 & 7 & 10 & 165 & 10 \\
2007 & A/RES/62/107 & 6 & 3 & 169 & 14 \\
2008 & A/RES/63/96 & 6 & 1 & 173 & 12 \\
2009 & A/RES/64/92 & 6 & 4 & 168 & 14 \\
2010 & A/RES/65/103 & 6 & 2 & 169 & 15 \\
2011 & A/RES/66/77 & 7 & 2 & 164 & 20 \\
2012 & A/RES/67/119 & 6 & 3 & 171 & 13 \\
\hline
\end{tabular}

Source: United Nations

Table 9: Repeated votes on a resolution on "Practices by Israel affecting human rights"

\begin{tabular}{llcccc}
\hline Year & UN vote & Against & Abstain & In favor & Not voting \\
\hline 1996 & A/RES/51/134 & 2 & 8 & 149 & 33 \\
1997 & A/RES/52/67 & 2 & 7 & 151 & 32 \\
1998 & A/RES/53/56 & 2 & 4 & 151 & 35 \\
1999 & A/RES/54/79 & 2 & 3 & 150 & 37 \\
2000 & A/RES/55/133 & 3 & 1 & 150 & 38 \\
2001 & A/RES/56/62 & 4 & 2 & 145 & 41 \\
2002 & A/RES/57/127 & 6 & 6 & 148 & 32 \\
2003 & A/RES/58/99 & 6 & 19 & 150 & 17 \\
2004 & A/RES/59/124 & 7 & 22 & 149 & 14 \\
2005 & A/RES/60/107 & 7 & 17 & 148 & 20 \\
2006 & A/RES/61/119 & 9 & 14 & 157 & 12 \\
2007 & A/RES/62/109 & 7 & 11 & 156 & 18 \\
2008 & A/RES/63/98 & 8 & 4 & 165 & 15 \\
2009 & A/RES/64/94 & 9 & 5 & 162 & 16 \\
2010 & A/RES/65/105 & 9 & 2 & 165 & 16 \\
2011 & A/RES/66/79 & 9 & 4 & 159 & 21 \\
2012 & A/RES/67/121 & 8 & 6 & 164 & 15 \\
\hline
\end{tabular}

Source: United Nations 
Table 10: Repeated votes on a resolution on "Limitations on Israel's borders and sovereignty"

\begin{tabular}{cccccc}
\hline Year & UN vote & Against & Abstain & In favor & Not voting \\
\hline 1996 & A/RES/51/190 & 3 & 21 & 133 & 35 \\
1997 & A/RES/52/207 & 2 & 14 & 137 & 39 \\
1998 & A/RES/53/196 & 2 & 12 & 144 & 34 \\
1999 & A/RES/54/230 & 3 & 5 & 132 & 52 \\
2000 & A/RES/55/209 & 2 & 3 & 147 & 40 \\
2001 & A/RES/56/204 & 4 & 4 & 148 & 36 \\
2002 & A/RES/57/269 & 4 & 4 & 155 & 29 \\
2003 & A/RES/58/229 & 4 & 10 & 157 & 21 \\
2004 & A/RES/59/251 & 5 & 11 & 156 & 20 \\
2005 & A/RES/60/183 & 6 & 8 & 156 & 22 \\
2006 & A/RES/61/184 & 6 & 9 & 164 & 13 \\
2007 & A/RES/62/181 & 7 & 6 & 166 & 13 \\
2008 & A/RES/63/201 & 8 & 5 & 164 & 15 \\
2009 & A/RES/64/185 & 8 & 7 & 165 & 12 \\
2010 & A/RES/65/179 & 8 & 5 & 167 & 12 \\
2011 & A/RES/66/225 & 7 & 6 & 167 & 13 \\
2012 & A/RES/67/229 & 7 & 9 & 170 & 7 \\
\hline
\end{tabular}

Source: United Nations 